\title{
Metformin in Oncology - How Far Is Its Repurposing as an Anticancer Drug?
}

\author{
Metformin v onkologii - jak daleko jsme od jeho etablování \\ coby protinádorového léku?
}

\author{
Pacal L., Kankova K. \\ Department of Pathophysiology, Faculty of Medicine, Masaryk University, Brno, Czech Republic
}

\begin{abstract}
Summary
Background: Metformin is the most commonly used antidiabetic drug with a plethora of proven metabolic and cardiovascular beneficial effects and exceptional safety profile. On top of the established metabolic effects, retrospective epidemiologic evidence shows that metformin use is associated with decreased cancer risk and/or improved disease prognosis in diabetic cancer patients on metformin compared to those treated with different antidiabetic drugs. This is a sound argument for eventual repurposing metformin as an adjuvant drug in oncology; however, evidence-based data are currently needed to establish this. Metformin is a biguanide that in the context of type 2 diabetes primarily targets the liver. Metformin inhibits oxidative phosphorylation which leads to the suppression of gluconeogenesis and causes decrease of blood glucose concentration. Mechanisms responsible for metformin anti-neoplastic effect have been investigated extensively, and key events seem to centralize around its ability to induce intracellular energetic stress with subsequent changes of metabolism resulting in cytostatic or cytotoxic action. Large clinical experience with metformin in the treatment of diabetes together with its plausible effects on different cancer cell types initiated a number of clinical trials that tested the hypothesis that metformin might have a beneficial effect in the treatment of cancer. Purpose: The aim of this review is to compile recent advances in our understanding of metformin antineoplastic effects and to give a summary of the results of recent clinical trials of metformin for treatment of different cancer types.
\end{abstract}

Key words

metformin - diabetes - cancer - treatment - clinical trial - AMPK

\section{Souhrn}

Východiska: Metformin je lékem první volby u diabetiků, lékem stále šíreji využívaným i v nediabetické populaci, a to zejména díky kombinaci efektivity a excelentního bezpečnostního profilu. Nad rámec známých metabolických efektů prokázaly retrospektivní epidemiologické studie, že užívání metforminu u diabetiků snižuje riziko vzniku nádorů a/nebo zlepšuje prognózu ve srovnání s těmi, kteří užívají jiná antidiabetika. Toto je velmi silný argument pro to, uvažovat o změně účelu indikace metforminu jako př́padného adjuvancia v onkologických indikacích, nicméně je bezpodmínečně nutné ověrit tuto domněnku v duchu medicíny založené na důkazech. Metformin patří mezi biguanidy a v kontextu diabetu typu 2 zvyšuje citlivost tkání k inzulinu. Účinkuje především na úrovni jater, kde inhibuje oxidativní fosforylaci, což vede k supresi glukoneogeneze a způsobuje pokles koncentrace glukózy v krvi. Působí také na svalové a tukové buňky, ve kterých zlepšuje utilizaci glukózy. Mechanizmy zodpovědné za protinádorový účinek metforminu jsou detailně studovány a zdá se, že nejdůležitější je jeho schopnost vyvolat intracelulární energetický stres a následně metabolické změny, které mají cytostatický nebo cytotoxický efekt. Rozsáhlá klinická zkušenost s metforminem $v$ léčbě diabetu v kombinaci s jeho prokázaným efektem na různé typy nádorových buněk vedla k zahájení mnoha klinických studií, které testovaly jeho potenciál při léčbě nádorủ. Cíl: Cílem této práce je shrnout současné znalosti o protinádorových účincích metforminu a výsledky recentních klinických studií s metforminem při léčbě různých typů nádorů.
The study was supported by the grant GA16-148295 from the Czech Science Foundation.

Tato studie byla podpořena grantem GA16-14829S Grantové agentury ČR.

The authors declare they have no potential conflicts of interest concerning drugs, products, or services used in the study.

Autoři deklarují, že $v$ souvislosti s předmětem studie nemaji žádné komerční zájmy.

The Editorial Board declares that the manuscript met the ICMJE recommendation for biomedical papers.

Redakční rada potvrzuje, že rukopis práce splnil ICMJE kritéria pro publikace zasílané do biomedicínských časopisů

Lukáš Pácal, PhD

Department of Pathophysiology

Faculty of Medicine

Masaryk University

Kamenice 5

62500 Brno

e-mail:paci@med.muni.cz

Submitted/Obdrženo: 26. 4. 2019

Accepted/Prijiato: 10. 12. 2019

doi: $10.14735 / a m k o 2020107$

\section{Klíčová slova}

metformin - diabetes - nádory - léčba - klinická studie - AMPK 


\section{Introduction}

Metformin is the $1^{\text {st }}$ line antidiabetic drug worldwide with an exceptional status because of its efficiency and safety profile. It is typically well tolerated, weight-neutral and does not cause hypoglycemia. Furthermore, metformin is inexpensive and can be safely combined with majority of antidiabetic drugs. Although its action is still not fully understood despite the long history of its use to treat type 2 diabetes mellitus (T2DM) - since 1957 in Europe and since 1995 in the US - metformin has been shown to impact multiple tissues through different molecular mechanisms. Not long ago, its use was extended to polycystic ovary syndrome, metabolic syndrome, prediabetes and lately also to gestational diabetes. Beyond the field of endocrinology and metabolic medicine, metformin became at the forefront of oncology. Recent epidemiological data consistently show increased incidence of certain types of cancers in diabetes mellitus, worse treatment response in diabetics and also non-negligible effect of antidiabetic treatments (namely metformin) on cancer outcomes. Both diabetes and cancer are prevalent diseases which make potential treatment overlap or synergy an extremely attractive idea. Metformin has been successfully used for T2DM treat- ment for more than 50 years and also there is a substantial evidence of its anticancer effect - these facts make metformin a clear candidate for repurposing as an adjuvant anticancer therapy. The aim of the current review is to a) briefly summarize recent understanding of molecular mechanism of metformin antidiabetic and anticancer effects; b) compile results of clinical trials in oncology that investigated the impact of metformin added to standard anticancer treatment in different solid tumors and; c) identify recent obstacles and issues preventing eventual progress in this area.

\section{Mechanisms of action mediating anti-diabetic effect of metformin} The major target of metformin is most likely the liver where it reaches much higher concentration than in the systemic circulation (plasma metformin concentration usually $10-40 \mu \mathrm{mol} / \mathrm{L}$ ) and majority of other human tissues [1]. The crucial antidiabetic effect of metformin is the inhibition of hepatic gluconeogenesis and increase of insulin sensitivity. At the molecular level, metformin accumulates in the mitochondria where it inhibits complex 1 of the respiratory chain [2] which leads to the subsequent decline in adenosine triphosphate (ATP) produc-

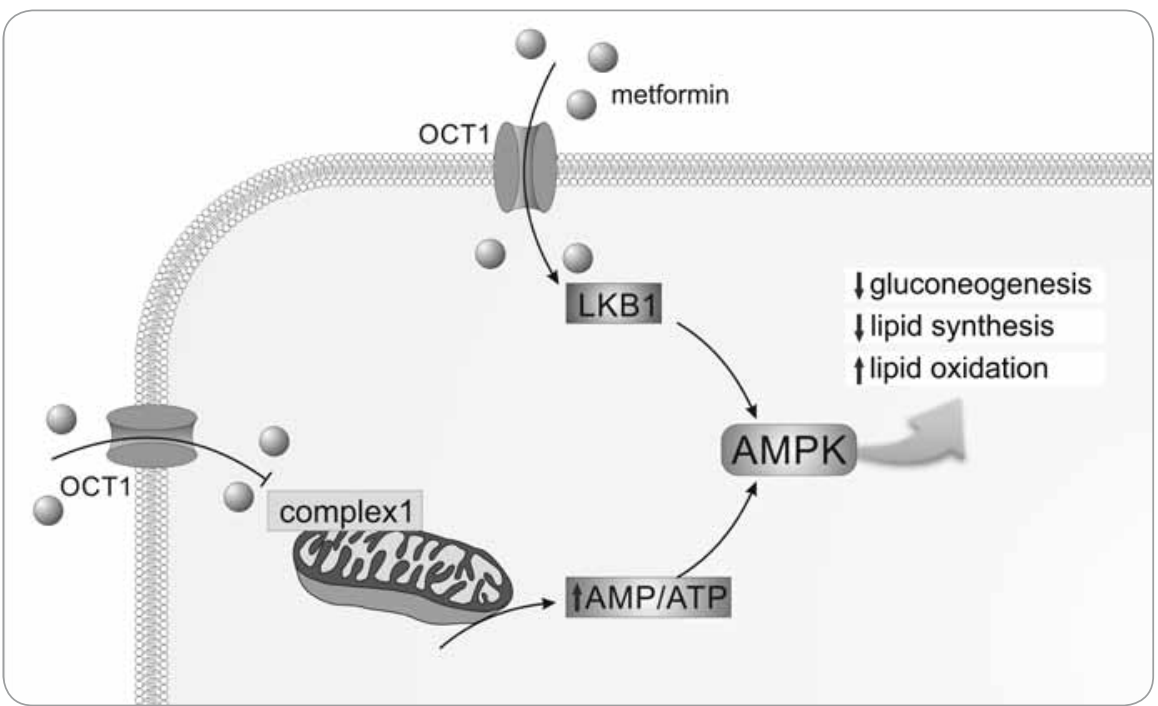

Fig. 1. The effect of metformin on hepatocytes.

Metformin activates AMPK through inhibition of complex 1 of the mitochondrial respiratory chain and through liver kinase B1. AMPK then inhibits gluconeogenesis and lipid synthesis and activates lipid oxidation.

AMP - adenosine monophosphate, AMPK - AMP-activated protein kinase, ATP - adenosine triphosphate, LKB1 - liver kinase B1, OCT1 - organic cation transporter 1

tion. As the gluconeogenesis is an energy consuming process, energetic stress causes its inhibition. The AMP-activated protein kinase (AMPK) plays a central role in mediating metformin therapeutic effects. AMPK - by means of detecting levels of AMP, adenosine diphosphate (ADP) and ATP - serves as a cellular energy sensor. Increased AMP/ATP and ADP/ATP ratios induced by shortage of ATP production, activates AMPK leading to a switch to catabolic processes replenishing cellular ATP while inactivating anabolic reactions consuming ATP. Besides gluconeogenesis, AMPK inhibits lipid synthesis and stimulates lipid oxidation through phosphorylation and subsequent activation of enzyme acetyl-CoA carboxylase [3]. Metformin also activates AMPK through liver kinase B1 [4] and, alternatively, through the lysosomal pathway [5]. Another mechanism (AMPKindependent) contributing to the suppression of gluconeogenesis operates via inhibition of mitochondrial enzyme glycerophosphate dehydrogenase [6]. Glycerophosphate dehydrogenase catalyses regeneration of $\mathrm{NAD}^{+}$from $\mathrm{NADH}$ which contributes to oxidative phosphorylation. However, $\mathrm{NAD}^{+}$is replenished also by malate/aspartate shuttle; thus, the contribution of glycerophosphate dehydrogenase inhibition to metformin metabolic effect repertoire must be established. Fig. 1 summarizes the effect of metformin on hepatocytes.

Recent evidence suggests that the gut is another target tissue of metformin - likely as important as the liver. Buse et al. [7] conducted randomized clinical trial using delayed-release metformin with decreased (by 50\%) absorption in the gut. Despite lower plasma concentration, patients receiving delayed-release metformin showed larger decrease of blood glucose than patients with immediate- or extended-release metformin. These data suggest gut-related effects of metformin. Several candidate mechanisms have been proposed from animal experiments including change of intestinal microbiota, metabolism of bile acids or secretion of glucagon-like peptide 1 [8].

Besides liver and gut, metformin is accumulated significantly in the kidneys and bladder which likely reflects its elimination route. 


\section{Epidemiological evidence linking diabetes and cancer and hypothetic pathogenic mechanisms}

There is growing epidemiological evidence indicating relationship between diabetes mellitus, namely T2DM, and increased incidence of certain types of cancer [9]. Moreover, mortality from cancer appears increased in people with pre-existing diabetes $[10,11]$. Finally, the effect of various types of glucose-lowering therapies, consistently documented for metformin, seems to modulate the risk of cancer incidence and cancer-associated mortality $[12,13]$. The relationship between T2DM and cancer can be principally direct/causal (e.g. diabetes creating the favorable microenvironment for cancer to develop) or indirect through shared risk factors such as obesity, poor dietary habits and physical inactivity.

Regarding the possibility of direct, biological relationship between diabetes and cancer, multiple metabolic derangements produced by chronic, undiagnosed (as is very often the cause of T2DM) or poorly compensated diabetes indeed hypothetically establish cancer-permissive environment. Energy substrate overload due to insulin resistance and relative insulin deficiency in frank T2DM leads to multiple alterations of intermediate metabolism $[14,15]$. The pro/oxidative state induces a profound and complex dysregulation of cellular metabolism (often described as gluco-/lipotoxicity) marked by the overproduction of an array of harmful metabolites from glycolytic intermediates, such as polyols, hexosamines, methylglyoxal, advanced glycation end-products etc.

Cancer cells have striking metabolic properties - mainly prevailing aerobic glycolysis (so called "Warburg effect") - that are according to current understanding the consequence of active reprogramming of cellular metabolism during the process of malignant transformation. Metabolic regulation is an inseparable component of cell proliferation machinery and has a tight link with activities of oncogenes and suppressor genes. The major purpose of metabolic reprogramming in cancer cells (but also in normal intensively proliferating cells) is to incorporate greater fraction of glucose metabolites into newly synthesized macromolecules. Some of the crucial master switches of these adaptations are flexibly regulated opposing insulin/phosphatidylinositol-3-kinase (PI3K)/AKT and LKB1/AMPK pathways converging at the level of mammalian target of rapamycin (mTOR, a regulator of protein synthesis and autophagy). There are several plausible pathogenic mechanisms in favor of hypothetically direct facilitating effect of diabetic milieu on cancer development and/or progression:

a) hyperglycemia (favouring "Warburg effect" [16]);

b) hyperinsulinemia (promoting cell proliferation and survival via insulin or IGF-1 receptors $[17,18]$ );

c) oxidative stress and inflammation (as a consequence of gluco- and lipotoxicity [19]);

e) decreased sex-hormone binding globulins in insulin resistance (leading to excess of free estrogens for estrogen-dependent tumors [20]);

f) excessive glycation (exerting proteomic and epigenetic changes altering cellular phenotype and regulations) and possibly several others $[21,14]$.

Increasing evidence also suggests that metformin has an immunomodulatory effect. Metabolic sensor AMPK is a possible link between metformin and immune system as AMPK has been shown to regulate T cell effector response in vivo [22]. Furthermore, metformin-induced activation of $\mathrm{AMPK}$ enhanced $\mathrm{CD}^{+} \mathrm{T}$ cell memory cells [23]. Recent study showed that metformin stimulates immune response to cancer cells through increasing the number of $\mathrm{CD}^{+}$tumor-infiltrating lymphocytes via inhibition of their apoptosis [24]. However, further investigation of metformin as an immunomodulator and its possible interaction with immunotherapy is warranted.

\section{Putative anticancer effects of metformin}

Metformin has gained large attention in 2005 when results of the observational study showing lower risk of cancers as- sociated with metformin use were published [25]. Since then, many analyses have been performed; substantial epidemiological evidence shows that metformin use is associated with reduced risk of many types of cancers, including colorectal, pancreatic, liver and others [26].

Although the notion of metformin as a possible modulator of cancer risk dates back to history, molecular mechanisms underlying metformin anticancer action (including issue of bioavailability, pharmacogenetics, effect in non-diabetics etc.) are still to be determined. Moreover, it is likely that the effect of metformin on cancer incidence may result from different mechanisms than the effect on cancer mortality. The glucose-lowering effect of metformin is a consequence of decreased hepatic gluconeogenesis and increased muscle glucose uptake. Molecular mechanisms responsible for these metabolic effects involve both AMPK-dependent and AMPK-independent events; the same mechanisms are likely to be responsible for metformin anticancer effects as recently extensively reviewed $[27,28]$.

Despite being supported by solid epidemiological and experimental evidence, there are still several concerns related to metformin use in cancer treatment. Not all tissues are exposed to equal and pharmacodynamically relevant metformin concentrations with highest concentration of metformin being consistently reported in portal circulation. Metformin molecule has a positive charge; therefore, its transport into the cells is an active process depending on the presence of organic cation transporters. Metformin enters the enterocytes through the plasma monoamine transporter (PMAT, encoded by the gene SLC29A4) and leaves the cell through organic cation transporter 1 (OCT1, encoded by SLC22A1) [27]. Metformin was shown to accumulate in cells with high expression of metformin transporters (e.g. OCT1 but also others), predominantly in hepatocytes [28]. Genetic polymorphism in genes encoding for organic cation transporters (several individual variants) were shown to have a pharmacogenetically relevant effect, i.e. their 
carriers exhibited impaired glucose lowering effect when metformin was prescribed. Individual response to metformin treatment was also studied using genome-wide approach [29]. The study found a single nucleotide polymorphism associated with better response to metformin treatment in patients with T2DM at a locus containing ATM, the ataxia telangiectasia mutated gene. Subsequent in vitro experiment linked ATM to activation of AMPK suggesting a possible involvement of cell cycle control and glycemic response to metformin.

\section{Animal studies and clinical trials with metformin as an adjuvant anticancer drug}

Given the putative pharmacodynamic restriction mentioned above (mediated by variable tissue expression of metformin transporters), it is not surprising that initially metformin was widely studied in relation to colorectal cancer (CRC), where concentration upon oral administration tends to be maximal. Initially, it was shown that metformin possessed chemoprotective effect in two rodent models of CRC [30,31]. The same laboratory conducted a study in human nondiabetic subjects investigating the effect of metformin treatment on the number of aberrant crypt foci. They found that metformin inhibits proliferation of enterocytes and also formation of aberrant crypt foci [32]. Next, the same authors initiated a randomized controlled trial in nondiabetic patients who underwent colorectal polypectomy [33]. Results of the phase III trial were published in 2016 [34] showing colonoscopy findings in 151 patients enrolled after 1 year of metformin or placebo administration. Metformin reduced prevalence and number of polyps together with indisputable safety for nondiabetic subjects as no serious adverse events were detected [34]. In another trial, metformin was also added to fluorouracil in patients with metastatic CRC [35]. In this phase II trial, sample size was unfortunately a major limitation as only 11 of 50 patients reached primary endpoint which was defined as a disease control at 8 weeks, and only those patients were further analyzed. The authors found that obese patients had longer, though statistically insignificant, median survival. Metformin treatment was generally well-tolerated. Finally, metformin was tested as a potential drug that might protect from adverse effects of oxaliplatin treatment, specifically from peripheral sensory neuropathy [36]. The authors reported a protective effect of metformin - namely less subjects with more advanced neuropathy and lower mean pain score in patients receiving metformin. Also biochemical intermediate traits - such as serum malondialdehyde and neurotensin - were lower in the metformin group.

The accumulation of epidemiologic evidence and findings from in vitro and animal experiments initiated a number of clinical trials testing metformin as a potential adjuvant treatment of many other cancer types (Tab. 1). Recently, 113 trials are ongoing or recruiting patients [37] (accessed December 2018). Nevertheless, 28 trials have been prematurely terminated because of a low recruitment rate or suffered from other design issues, other than limited sample size. 121 studies were completed but only 17 released results so far. For example, in a placebo-controlled phase II randomized clinical trial, metformin did not improve outcomes in patients with advanced pancreatic cancer [38]. However, this trial is quite controversial [39] since patients receiving metformin had more advanced disease (based on values of marker (A19.9), and they also received fewer treatment cycles. Results of another phase II trial in patients with advanced pancreatic cancer receiving standard systemic therapy with or without metformin ( $2 \mathrm{~g}$ daily) were reported [40] with no significant difference in 6-months progression-free, disease-free and overall survival between groups.

Metformin was also tested in addition to aromatase inhibitor in women with hormone receptor positive advanced breast cancer [41]. Metformin did not affect progression-free survival or overall survival. However, only women with advanced or metastatic breast cancer were enrolled. The influence of metformin on metabolic profile of women with early breast cancer was studied [42]; 32 women with baseline insulin $>45 \mathrm{pmol} / \mathrm{L}$ received $1,500 \mathrm{mg}$ of metformin per day for 6 months. After intervention, women had significantly lower fasting insulin, total and LDL-cholesterol and improved insulin sensitivity. The impact of metformin on selected metabolic and hormonal parameters in women with breast cancer was tested in a randomized study [43]. During first 3 months, women received $500 \mathrm{mg}$ daily, then $1,000 \mathrm{mg}$ daily for 1 month and for the last 5 months were randomized to receive 1,000 or $1,500 \mathrm{mg}$. The arm with $1,500 \mathrm{mg}$ per day had significantly lower plasma insulin, HOMA index, testosterone and free androgen index. Biological effects of metformin were investigated also in non-diabetic women with operable breast cancer $[44,45]$. Experimental design was similar for both studies. Metformin was administered two weeks before surgery - $500 \mathrm{mg}$ daily for one week, then $1 \mathrm{~g}$ twice a day for another week, while control group did not receive metformin. Cancer biopsy was performed twice - before initiation of metformin and at the time of surgery - and tissue samples were analyzed using immunochemistry. In the first study [44], phospho-AMPK was upregulated while phospho-Akt was downregulated in the metformin group. Tissue insulin receptor and serum insulin did not change during treatment in the metformin group, while both parameters were higher at the time of surgery in the control group. Ki-67 (a marker of cell proliferation) was significantly lower after treatment with metformin. In the second study [45], Ki-67 was decreased in the metformin group. Also, mRNA expression of several genes was decreased, including phosphodiesterase $3 \mathrm{D}$ (a regulator of AMPK), TP53, BRCA and others. The effect of metformin on cancer proliferation marker Ki-67 was tested also in non-diabetic women with breast cancer 4 weeks prior surgery [46]. Women received $850 \mathrm{mg}$ of metformin or placebo, biopsy and blood samples for measurement of selected markers were taken at baseline and at the time of surgery. The effect of metformin varied based on metabolic and tumor charac- 
Tab. 1. Clinical trials examining the effect of metformin on cancer.

\begin{tabular}{|c|c|c|c|c|}
\hline $\begin{array}{l}\text { Cancer } \\
\text { site }\end{array}$ & Study author & Population & $\begin{array}{c}\text { Sample size } \\
\text { (metformin/ } \\
\text { placebo) }\end{array}$ & Primary outcome \\
\hline \multirow{4}{*}{$\begin{array}{l}\text { colorectal } \\
\text { cancer }\end{array}$} & Hosono K [32] & $\begin{array}{l}\text { nondiabetic patients with aberrant } \\
\text { crypt foci }\end{array}$ & $9 / 14$ & $\begin{array}{l}\text { number of rectal aberrant } \\
\text { crypt foci }\end{array}$ \\
\hline & Higurashi T [34] & $\begin{array}{l}\text { non-diabetic adults with previous CRC } \\
\text { adenomas or polyps resected by endoscopy }\end{array}$ & $71 / 62$ & $\begin{array}{l}\text { number and prevalence of } \\
\text { adenomas or polyps }\end{array}$ \\
\hline & Miranda VC [35] & patients with metastatic CRC & $50 /-$ & disease control rate at 8 weeks \\
\hline & El-Fatatry BM [36] & patients with stage III CRC & $20 / 20$ & oxaliplatin-induced neuropathy \\
\hline \multirow{2}{*}{$\begin{array}{l}\text { pancreatic } \\
\text { cancer }\end{array}$} & Kordes S [38] & $\begin{array}{l}\text { patients aged } 18 \text { years and older with } \\
\text { advanced pancreatic cancer }\end{array}$ & $60 / 61$ & OS at 6 months \\
\hline & Reni M [40] & $\begin{array}{l}\text { patients aged } 18 \text { years and older with } \\
\text { metastatic pancreatic cancer }\end{array}$ & $31 / 29$ & 6-months PFS \\
\hline \multirow{10}{*}{$\begin{array}{l}\text { breast } \\
\text { cancer }\end{array}$} & Zhao Y [41] & $\begin{array}{l}\text { postmenopausal women with hormone } \\
\text { receptor-positive locally advanced or } \\
\text { metastatic breast cancer }\end{array}$ & $30 / 30$ & PFS \\
\hline & Goodwin PJ [42] & $\begin{array}{l}\text { women with early breast cancer with } \\
\text { baseline insulin }>45 \mathrm{pmol} / \mathrm{L}\end{array}$ & $32 /-$ & $\begin{array}{l}\text { fasting insulin, cholesterol, insulin } \\
\text { sensitivity }\end{array}$ \\
\hline & Campagnoli C [43] & $\begin{array}{l}\text { postmenopausal women with breast } \\
\text { cancer without diabetes and with basal } \\
\text { testosterone levels }>0.28 \mathrm{ng} / \mathrm{mL}\end{array}$ & $96 /-$ & $\begin{array}{l}\text { serum levels of insulin and } \\
\text { testosterone }\end{array}$ \\
\hline & Hadad SM [44] & $\begin{array}{l}\text { non-diabetic women with operable invasive } \\
\text { breast cancer }\end{array}$ & $17 / 22$ & $\begin{array}{l}\text { immunohistochemistry (AMPK, } \\
\text { pAKT, Ki-67, insulin receptor) }\end{array}$ \\
\hline & Hadad S [45] & $\begin{array}{l}\text { non-diabetic women with operable invasive } \\
\text { breast cancer }\end{array}$ & $17 / 22$ & $\begin{array}{c}\mathrm{Ki}-67 \text { and expression of selected } \\
\text { genes }\end{array}$ \\
\hline & DeCensi A [46] & $\begin{array}{l}\text { non-diabetic women with breast cancer } \\
\text { prior surgery }\end{array}$ & $100 / 100$ & $\begin{array}{l}\text { Ki-67, serum markers (HOMA-IR, } \\
\text { C-peptide) }\end{array}$ \\
\hline & Kalinsky K [47] & $\begin{array}{l}\text { overweight/obese non-diabetic patients } \\
\text { with stage } 0 \text {-III breast cancer }\end{array}$ & $35 /-$ & tumour proliferation change (Ki-67) \\
\hline & Niraula S [48] & $\begin{array}{l}\text { newly diagnosed untreated non-diabetic } \\
\text { women with breast cancer }\end{array}$ & $39 /-$ & Ki-67 \\
\hline & Sonnenblick A [49] & $\begin{array}{c}\text { women with diabetes and HER2 positive } \\
\text { breast cancer }\end{array}$ & $260 / 186$ & DFS, distant DFS, OS \\
\hline & Davis SR [50] & $\begin{array}{l}\text { postmenopausal women with hormone } \\
\text { receptor-positive breast cancer }\end{array}$ & $50 / 52$ & $\begin{array}{l}\text { tamoxifen-induced endometrial } \\
\text { changes and insulin resistance }\end{array}$ \\
\hline \multirow{5}{*}{$\begin{array}{l}\text { endo- } \\
\text { metrial } \\
\text { cancer }\end{array}$} & Hanawa S [51] & women with endometrial cancer & $27 /-$ & protein phosphatase $2 \mathrm{~A}$ \\
\hline & Schuler KM [52] & obese women with endometrial cancer & $20 /-$ & $\begin{array}{l}\text { immunohistochemistry (Ki-67, } \\
\text { estrogen receptor, AMPK, mTOR) }\end{array}$ \\
\hline & Sivalingam VN [53] & $\begin{array}{l}\text { women with atypical endometrial } \\
\text { hyperplasia and endometrial cancer }\end{array}$ & $28 / 12$ & $\begin{array}{l}\text { phosphorylated PI3K-AKT-mTOR, } \\
\text { cell proliferation (Ki-67) }\end{array}$ \\
\hline & Mitsuhashi A [54] & patients with endometrial cancer & $31 /-$ & $\begin{array}{l}\text { cell proliferation (Ki-67), circulating } \\
\text { factors (insulin, glucose, leptin) }\end{array}$ \\
\hline & Mitsuhashi A [55] & $\begin{array}{l}\text { patients with atypical endometrial } \\
\text { hyperplasia and endometrial cancer }\end{array}$ & $36 /-$ & relapse-free survival after remission \\
\hline \multirow{2}{*}{$\begin{array}{l}\text { non- } \\
\text { squamous } \\
\text { non-small } \\
\text { cell lung } \\
\text { cancer }\end{array}$} & Marrone KA [56] & $\begin{array}{l}\text { patients with chemotherapy-naïve advanced } \\
\text { or metastatic non-squamous NSCLC }\end{array}$ & $18 / 6$ & 1-year PFS \\
\hline & Parikh AB [57] & patients with advanced NSCLC & $14 /-$ & PFS \\
\hline
\end{tabular}

CRC - colorectal cancer, NSCLC - non-squamous non-small-cell lung cancer, OS - overall survival, PFS - progression-free survival, AMPK - AMP-activated protein kinase, HOMA-IR - homeostatic model assessment of insulin resistance, DFS - disease-free survival, mTOR - mammalian target of rapamycin, PI3K - phosphatidylinositol 3-kinase 
teristics. Metformin decreased Ki-67 but only in women with HOMA > 2.8. Tumor proliferation was evaluated in another study [47]. Women with body mass index $(\mathrm{BMI})>25 \mathrm{~kg} / \mathrm{m}^{2}$ were taking $1,500 \mathrm{mg}$ of metformin daily. Metformin did not affect Ki-67 but reduced total cholesterol, BMI and leptin. In the next study, metformin was administered to women with newly diagnosed breast cancer prior to surgery $(500 \mathrm{mg}$ per day for a median of 18 days) [48]. Its use was associated with decrease of BMI, weight, HOMA index and also Ki-67. Metformin was also studied in the context of human epidermal growth factor receptor 2 (HER2) positive breast cancer [49]. Of 8,381 patients enrolled, $5.3 \%$ had diabetes. Those untreated with metformin showed worse disease-free and overall survival than patients receiving metformin. Another trial studied the effect of metformin on endometrial changes and insulin resistance induced by tamoxifen in breast cancer [50]. Postmenopausal women with hormone receptor-positive breast cancer were randomized to receive $850 \mathrm{mg}$ of metformin $2 \times$ daily or placebo for 52 weeks. Endometrial thickness at the end of trial was significantly lower in the metformin group. Reductions of parameters related to insulin resistance (weight, waist circumference and HOMA-IR) were greater in women with metformin.

Mechanism of antitumor metformin action was investigated in patients with endometrial cancer [51]. The authors found that metformin inhibits expression of protein phosphatase $2 \mathrm{~A}$ which is associated with insulin resistance. Antiproliferative and metabolic effects of metformin were also studied [52]. Obese women with endometrial cancer received metformin ( $850 \mathrm{mg}$ daily) for up to 4 week prior surgery. Cell proliferation as well as expression of phosphorylated AMPK and AKT were reduced by metformin. Another study with similar design enrolled women with endometrial cancer receiving $850 \mathrm{mg}$ of metformin twice a day between diagnosis and hysterectomy (median duration 20 days) [53]. Tissue samples before and after metformin treatment were obtained and evaluated for markers of cell proliferation. Metformin induced significant reduction of Ki-67. Mitsuhashi et al. also studied the effect of metformin on cell proliferation in endometrial cancer [54]. Patients received 1,500$2,250 \mathrm{mg}$ of metformin daily or no drug for 4-6 weeks before surgery. Metformin use reduced $\mathrm{Ki}-67$ and circulating insulin, glucose, insulin-like growth factor 1 and leptin. The same authors administered metformin together with medroxyprogesterone acetate to patients with atypical endometrial hyperplasia and endometrial cancer in a phase II trial [55]. Primary endpoint was relapse-free survival, and metformin was shown to inhibit relapse after medroxyprogesterone therapy.

Another phase II trial enrolled patients with advanced or metastatic non-squamous non-small-cell lung cancer [56]. Patients received carboplatin, paclitaxel and bevacuzimab with or without metformin. Those receiving metformin in addition to standard therapy showed higher proportion of reaching 1-year progression-free survival compared to historical control (47 vs. $15 \%$ ). Median survival of those with and without metformin was similar. Metformin was also administered to patients with advanced non-small-cell lung cancer in a phase II trial. The main limitation was sample size as only 14 patients were enrolled [57].

Retrospective analysis of phase II and III clinical trials in patients with metastatic renal cell carcinoma was performed [58]. The study focused on overall survival and stratified patients with carcinoma according to the presence/absence of diabetes and the type of antidiabetic treatment. Total of 4,736 patients included 486 diabetics, and of those, 218 received metformin. Overall survival was not affected by metformin. However, diabetic patients receiving sunitinib and metformin had longer overall survival than those with other antidiabetic drugs ( 29.3 vs. 29.0 months).

\section{Conclusions}

Despite convergence between epidemiologic data and results of in vitro experiments and animal studies, there are still many issues regarding the evidence-based used of metformin in oncology.
Major limitations of studies (both experimental and human trials) published so far can be summarized as follows: epidemiologic evidence comes from observational studies that have not been designed to study the effect of metformin treatment on cancer and related outcomes. Secondly, concentrations of metformin used in in vitro experiments are markedly higher than metformin concentration in the plasma and target tissues of human subjects. Of all cancer types, only those that affect the gut might be exposed to similar metformin concentrations as approximately $50 \%$ of metformin is not absorbed [59] and accumulates in the gut mucosa. Finally, design of clinical studies considers mostly very advanced stages of cancers and short-term metformin administration, therefore probably a priori limiting its effectiveness.

In conclusion, further studies of anticancer effect of metformin are warranted and might require different study designs (especially in long-term users) rather than ad hoc adjuvant administration as suggested in the analysis of UK-based database showing lower risk of breast cancer in women with T2DM using metformin long-term [60]. Therefore, patients receiving metformin from early stages may have a bigger chance to benefit, and adequately powered studies explicitly testing this hypothesis are urgently needed.

\section{References}

1. He L, Wondisford FE. Metformin action: concentrations matter. Cell Metab 2015; 21(2): 159-162. doi: 10.1016/ j.cmet.2015.01.003.

2. Owen MR, Doran E, Halestrap AP. Evidence that metformin exerts its anti-diabetic effects through inhibition of complex 1 of the mitochondrial respiratory chain. Biochem J 2000; 348: 607-614.

3. Fullerton MD, Galic S, Marcinko Ket al. Single phosphorylation sites in $\mathrm{Acc} 1$ and $\mathrm{Acc} 2$ regulate lipid homeostasis and the insulin-sensitizing effects of metformin. Nat Med 2013; 19(12): 1649-1654. doi: 10.1038/nm.3372.

4. Zhou G, Myers R, Li Y et al. Role of AMP-activated protein kinase in mechanism of metformin action. J Clin Invest 2001; 108(8): 1167-1174. doi: 10.1172/JCl13505.

5. Zhang CS, Li M, Ma T et al. Metformin activates AMPK through the lysosomal pathway. Cell Metab 2016; 24(4): 521-522. doi: 10.1016/j.cmet.2016.09.003.

6. Madiraju AK, Erion DM, Rahimi $Y$ et al. Metformin suppresses gluconeogenesis by inhibiting mitochondrial glycerophosphate dehydrogenase. Nature 2014; 510(7506): 542-546. doi: 10.1038/nature13270.

7. Buse JB, DeFronzo RA, Rosenstock J et al. The primary glucose-lowering effect of metformin resides in the gut, 
not the circulation: results from short-term pharmacokinetic and 12-week dose-ranging studies. Diabetes Care 2016; 39(2): 198-205. doi: 10.2337/dc15-0488.

8. Song R. Mechanism of metformin: a tale of two sites. Diabetes Care 2016: 39: 187-9.

9. Giovannucci E, Harlan DM, Archer MC et al. Diabetes and cancer: a consensus report. Diabetes Care 2010; 33(7): 1674-1685. doi: 10.2337/dc10-0666.

10. Renehan AG, Yeh HC, Johnson JA et al. Diabetes and cancer (2): evaluating the impact of diabetes on mortality in patients with cancer. Diabetologia 2012; 55(6): 1619 1632. doi: 10.1007/s00125-012-2526-0.

11. Barone BB, Yeh HC, Snyder CF et al. Long-term allcause mortality in cancer patients with preexisting diabetes mellitus: a systematic review and meta-analysis. JAMA 2008; 300(23): 2754-2764. doi: 10.1001/jama.2008.824

12. Johnson JA, Carstensen B, Witte D et al. Diabetes and cancer (1): evaluating the temporal relationship between type 2 diabetes and cancer incidence. Diabetologia 2012 55(6): 1607-1618. doi: 10.1007/s00125-012-2525-1.

13. Jalving $M$, Gietema JA, Lefrandt JD et al. Metformin: taking away the candy for cancer? Eur J Cancer 2010; 46 2369-2380. doi: 10.1016/j.ejca.2010.06.012

14. Brownlee M. Biochemistry and molecular cell biology of diabetic complications. Nature 2001; 414(6865): 813820. doi: 10.1038/414813a

15. Du X, Edelstein D, Obici S et al. Insulin resistance reduces arterial prostacyclin synthase and eNOS activities by increasing endothelial fatty acid oxidation. J Clin Invest 2006; 116(4): 1071-1080. doi: 10.1172/JCI23354.

16. Johnson JA, Pollak M. Insulin, glucose and the increased risk of cancer in patients with type 2 diabetes. Diabetologia 2010; 53(10): 2086-2088. doi: 10.1007/s00125010-1855-0.

17. Pollak M. Insulin and insulin-like growth factor signalling in neoplasia. Nat Rev Cancer 2008; 8: 915-928. doi: 10.1038/nrc2536.

18. Pisani P. Hyper-insulinaemia and cancer, meta-analyses of epidemiological studies. Arch Physiol Biochem 2008: 114(1): 63-70 doi: 10.1080/13813450801954451.

19. Reuter S, Gupta SC, Chaturvedi MM et al. Oxidative stress, inflammation, and cancer: how are they linked? Free Radic Biol Med 2010; 49(11): 1603-1616. doi: 10.1016/j.freeradbiomed.2010.09.006.

20. van Kruijsdijk RC, van der Wall E, Visseren FL. Obesity and cancer: the role of dysfunctional adipose tissue. Cancer Epidemiol Biomarkers Prev 2009; 18(10): 2569-2578. doi: 10.1158/1055-9965.EPI-09-0372.

21. Kankova K, Hrstka R. Cancer as a metabolic disease and diabetes as a cancer risk? Klin Onkol 2012; 25 (Suppl 2): 2S26-2S31. doi: 10.14735/amko20122S26.

22. Blagih J, Coulombe F, Vincent EE et al. The energy sensor AMPK regulates $T$ cell metabolic adaptation and effector responses in vivo. Immunity 2015; 42(1): 41-54. doi: 10.1016/j.immuni.2014.12.030.

23. Pearce EL, Walsh MC, Cejas PJ et al. Enhancing CD8 T-cell memory by modulating fatty acid metabolism. Nature 2009; 460(7251): 103-107. doi: 10.1038/nature08097. 24. Eikawa S, Nishida M, Mizukami S et al. Immune-mediated antitumor effect by type 2 diabetes drug, metformin. Proc Natl Acad Sci USA 2015; 112(6): 1809-1814. doi: 10.1073/pnas.1417636112.

25. Evans JM, Donnelly LA, Emslie-Smith AM et al. Metformin and reduced risk of cancer in diabetic patients. BMJ 2005; 330(7503): 1304-1305. doi: 10.1136/bmj.38415.708634.F7.

26. Noto H, Goto A, Tsujimoto T et al. Cancer risk in diabetic patients treated with metformin: a systematic review and meta-analysis. PLoS One 2012; 7(3): e33411. doi: 10.1371/journal.pone.0033411.

27. Foretz M, Guigas B, Bertrand L et al. Metformin: from mechanisms of action to therapies. Cell Metab 2014 20(6): 953-966. doi: 10.1016/j.cmet.2014.09.018.
28. Pollak M. Potential applications for biguanides in oncology. J Clin Invest 2013; 123(9): 3693-3700. doi: 10.1172/JCl67232.

29. Zhou K, Bellenguez C, Spencer CC et al. Common variants near ATM are associated with glycemic response to metformin in type 2 diabetes. Nat Genet 2011;43(2): 117 120. doi: 10.1038/ng.735.

30. Tomimoto $A$, Endo $H$, Sugiyama $M$ et al. Metformin suppresses intestinal polyp growth in ApcMin/+ mice Cancer Sci 2008; 99(11): 2136-2141. doi: 10.1111/j.13497006.2008.00933.x.

31. Hosono K, Endo H, Takahashi H et al. Metformin sup presses azoxymethane-induced colorectal aberrant crypt foci by activating AMP-activated protein kinase Mol Carcinog 2010; 49(7): 662-671. doi: 10.1002/mc.20 637

32. Hosono K, Endo H, Takahashi H et al. Metformin sup presses colorectal aberrant crypt foci in a short-term clinical trial. Cancer Prev Res (Phila) 2010; 3(9): 1077-1083. do: 10.1158/1940-6207.CAPR-10-0186.

33. Higurashi T, Takahashi H, Endo H et al. Metformin efficacy and safety for colorectal polyps: a double-blind randomized controlled trial. BMC Cancer 2012; 12: 118. doi: 10.1186/1471-2407-12-118.

34. Higurashi T, Hosono K, Takahashi H et al. Metformin for chemoprevention of metachronous colorectal adenoma or polyps in post-polypectomy patients without diabetes: a multicentre double-blind, placebo-controlled, ran domised phase 3 trial. Lancet Oncol 2016; 17(4): 475-483. doi: 10.1016/S1470-2045(15)00565-3.

35. Miranda VC, Braghiroli MI, Faria LD et al. Phase 2 tria of metformin combined with 5-fluorouracil in patients with refractory metastatic colorectal cancer. Clin Colorectal Cancer 2016; 15(4): 321-328.e1. doi: 10.1016/j. clcc.2016.04.011.

36. El-Fatatry BM, Ibrahim OM, Hussien FZ et al. Role of metformin in oxaliplatin-induced peripheral neuropathy in patients with stage III colorectal cancer: randomized controlled study. Int J Colorectal Dis 2018 32(12): $1675-$ 1683. doi: 10.1007/s00384-018-3104-9.

37. ClinicalTrials.gov. U.S National Library of Medicine. [online]. Available from: https: //clinicaltrials.gov/.

38. Kordes S, Pollak MN, Zwinderman AH et al. Metformin in patients with advanced pancreatic cancer: a double-blind, randomised, placebo-controlled phase 2 trial. ancet Oncol 2015; 16(7): 839-847. doi: 10.1016/S14702045(15)00027-3.

39. Gyawali B, Pantziarka P, Crispino S et al. Does the oncology community have a rejection bias when it comes to repurposed drugs? Ecancermedicalscience 2018; 12 ed76. doi: 10.3332/ecancer.2018.ed76.

40. Reni M, Dugnani E, Cereda S et al. (Ir)relevance of metformin treatment in patients with metastatic pancreatic cancer: an open-label, randomized phase II trial. Clin Cancer Res 2016; 22(5): 1076-1085. doi: 10.1158/1078-0432. CCR-15-1722.

41. Zhao $Y$, Gong $C$, Wang $Z$ et al. A randomized phase Il study of aromatase inhibitors plus metformin in pre treated postmenopausal patients with hormone recepto positive metastatic breast cancer. Oncotarget 2017; 8(48): 84224-84236. doi: 10.18632/oncotarget.20478.

42. Goodwin PJ, Pritchard Kl, Ennis M et al. Insulin-lowering effects of metformin in women with early breas cancer. Clin Breast Cancer 2008; 8(6): 501-505. doi: 10.3816/CBC.2008n.060.

43. Campagnoli $C$, Pasanisi P, Abbà $C$ et al. Effect of different doses of metformin on serum testosterone and insulin in non-diabetic women with breast cancer: a randomized study. Clin Breast Cancer 2012; 12(3): 175-182. doi: 10.1016/j.clbc.2012.03.004

44. Hadad SM, Coates P, Jordan LB et al. Evidence for biological effects of metformin in operable breast cance biomarker analysis in a pre-operative window of opportu- nity randomized trial. Breast Cancer Res Treat 2015; 150(1): 149-155. doi: 10.1007/s10549-015-3307-5.

45. Hadad S, Iwamoto T, Jordan L et al. Evidence for biological effects of metformin in operable breast cancer: a pre-operative, window-of-opportunity, randomized trial. Breast Cancer Res Treat 2011; 128(3): 783-794. doi: 10.1007/s10549-011-1612-1.

46. DeCensi A, Puntoni M Gandini S et al. Differential effects of metformin on breast cancer proliferation according to markers of insulin resistance and tumor subtype in a randomized presurgical trial. Breast Cancer Res Treat 2014; 148(1): 81-90. doi: 10.1007/s10549-014-3141-1. 47. Kalinsky K, Crew KD, Refice $S$ et al. Presurgical trial of metformin in overweight and obese patients with newly diagnosed breast cancer. Cancer Invest 2014; 32(4): $150-$ 157. doi: 10.3109/07357907.2014.889706.

48. Niraula S, Dowling RJ, Ennis M et al. Metformin in early breast cancer: a prospective window of opportunity neoadjuvant study. Breast Cancer Res Treat 2012; 135(3): 821-830. doi: 10.1007/s10549-012-2223-1.

49. Sonnenblick A, Agbor-Tarh D, Bradbury I et al. Impact of diabetes, insulin, and metformin use on the outcome of patients with human epidermal growth factor receptor 2-positive primary breast cancer: analysis from the ALTTO phase III randomized trial. J Clin Oncol 2017; 35(13): 1421 1429. doi: 10.1200/JCO.2016.69.7722.

50. Davis SR, Robinson PJ, Jane F et al. The benefits of adding metformin to tamoxifen to protect the endometrium-A randomized placebo-controlled trial. Clin Endocrinol (Oxf) 2018; 89(5): 605-612. doi: 10.1111/cen. 13830

51. Hanawa S, Mitsuhashi A, Shozu M. Antitumor effects of metformin via indirect inhibition of protein phosphatase 2A in patients with endometrial cancer. PLoS One 2018; 13(2): e0192759. doi: 10.1371/journal.pone.0192759. 52. Schuler KM, Rambally BS, DiFurio MJ et al. Antiproliferative and metabolic effects of metformin in a preoperative window clinical trial for endometrial cancer. Cancer Med 2015; 4(2): 161-173. doi: 10.1002/cam4.353.

53. Sivalingam VN, Kitson S, McVey R et al. Measuring the biological effect of presurgical metformin treatment in endometrial cancer. Br J Cancer 2016; 114: 281-289. doi: 10.1038/bjc.2015.453.

54. Mitsuhashi A, Kiyokawa T, Sato $Y$ et al. Effects of metformin on endometrial cancer cell growth in vivo: a preoperative prospective trial. Cancer 2014; 120(19): 2986-2995. doi: 10.1002/cncr.28853.

55. Mitsuhashi A, Sato Y, Kiyokawa T et al. Phase II study of medroxyprogesterone acetate plus metformin as a fertility-sparing treatment for atypical endometrial hyperplasia and endometrial cancer. Ann Oncol 2016; 27(2): 262-266. doi: 10.1093/annonc/mdv539.

56. Marrone KA, Zhou X, Forde PM et al. A randomized phase II study of metformin plus paclitaxel/carboplatin/bevacizumab in patients with chemotherapy-naïve advanced or metastatic nonsquamous non-small cell lung cancer. Oncologist 2018; 23(7): 859-865. doi; 10.1634/theoncologist.2017-0465.

57. Parikh AB, Kozuch P, Rohs N et al. Metformin as a repurposed therapy in advanced non-small cell lung cancer (NSCLC): results of a phase II trial. Invest New Drugs 2017; 35(6): 813-819. doi: 10.1007/s10637-017-0511-7.

58. Hamieh L, McKay RR, Lin X et al. Effect of metformin use on survival outcomes in patients with metastatic renal cell carcinoma. Clin Genitourin Cancer 2017; 15(2): 221-229. doi: 10.1016/j.clgc.2016.06.017

59. Graham GG, Punt J, Arora M et al. Clinical pharmacokinetics of metformin. Clin Pharmacokinet 2011: 50(2): 8198. doi: 10.2165/11534750-000000000-00000.

60. Bodmer M, Meier C, Krähenbühl S et al. Long-term metformin use is associated with decreased risk of breast cancer. Diabetes Care 2010; 33(6): 1304-1308. doi: 10.2337/dc09-1791. 